Volume 118

Issue 1 Dickinson Law Review - Volume 118,

2013-2014

6-1-2013

\title{
Can Franchisee Associations Serve as a Substitute for Franchisee Protection Laws?
}

Robert W. Emerson

Uri Benoliel

Follow this and additional works at: https://ideas.dickinsonlaw.psu.edu/dlra

\section{Recommended Citation}

Robert W. Emerson \& Uri Benoliel, Can Franchisee Associations Serve as a Substitute for Franchisee Protection Laws?, 118 Dick. L. REV. 99 (2013).

Available at: https://ideas.dickinsonlaw.psu.edu/dlra/vol118/iss1/4

This Article is brought to you for free and open access by the Law Reviews at Dickinson Law IDEAS. It has been accepted for inclusion in Dickinson Law Review by an authorized editor of Dickinson Law IDEAS. For more information, please contact lja10@psu.edu. 


\title{
Can Franchisee Associations Serve as a Substitute for Franchisee Protection Laws?
}

\author{
Robert W. Emerson* and Uri Benoliel**
}

\begin{abstract}
The most vital debate in franchise law over the last few decades has focused on whether state or federal law should protect franchisees from the potentially opportunistic behavior of franchisors. Several states, such as California, Massachusetts, and Vermont, are considering the adoption of laws protecting franchisees against franchisor opportunism. At the federal level, several franchisee protections laws have been introduced, but so far all have been rejected.

Franchisor advocates suggest that franchisee protection laws are superfluous. Deeply ingrained in franchisor advocates' opposition to such legislation is the belief that independent franchisee associations, namely trade associations formed by franchisees within a single franchise chain, serve as a sufficient barrier against franchisor opportunism. More specifically, franchisor advocates assume that by collectivizing a large percentage of the franchisees in the franchise system, an independent franchisee association improves the bargaining position of franchisees vis-à-vis franchisors. As a result, the association is assumed to succeed in negotiating contract terms that protect franchisees from franchisor opportunism and thereby eliminate the need for franchisee protection laws.

This Article questions the idea that independent franchisee associations can prevent franchisor opportunism and otherwise serve as a substitute for franchisee protection laws. Focusing on the implicit assumption that such associations exist, or at least have the potential to

* Huber Hurst Professor of Business Law \& Legal Studies, Warrington College of Business Administration, University of Florida. B.A., Sewanee: University of the South, 1978; J.D., Harvard Law School, 1982.

** Assistant Professor, College of Law and Business. J.S.D., University of California, Berkeley, 2006; LL.M., Columbia University, 2005; LL.B., Hebrew University of Jerusalem, 2003.

We are grateful to Rupert Barkoff, Lisa Bernstein, Eric Karp, Benjamin Lawrence, Gideon Parchomovsky, Andrew Selden, and Eyal Zamir for their invaluable comments and critique.
\end{abstract}


exist, this Article argues that, in most cases, franchisees are unlikely to establish independent franchisee associations in the first place-mainly because under current law the expected costs borne by the franchisee in leading the establishment of an association exceed the expected benefits. That is, as federal and most state laws fail to adequately prohibit the franchisor's retaliatory termination of the franchise or other reprisals against a franchisee association leader, the probability of such retribution is significant; conversely, the probability that the franchisee will form a successful and sustainable association is very low. First, franchisors often establish, fund, and control a competing franchisee committee, known as the franchisor advisory council, which is likely to reduce considerably the probability that an independent franchisee association will operate successfully. Second, franchisees normally have little incentive to join and actively participate in an already functioning independent franchisee association for several reasons, including franchisee free-riding, franchisee fear of retaliation by franchisors, and economic incentives provided by franchisors to franchisees for not joining such associations.

\section{Table of Contents}

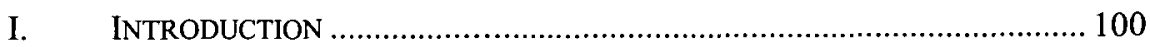

II. FRANCHISEE PROTECTION LAWS-OVVERIEW ................................. 105

III. THE FRANCHISOR ADVOCATES' VIEW ............................................... 107

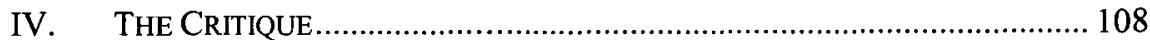

A. High Expected Costs for Franchisee Association Leader ............. 109

1. High Retaliation Costs ........................................................... 109

2. High Probability of Retaliation ............................................. 112

B. Low Expected Benefits for Franchisee Association Leader.......... 119

1. Franchisor Advisory Council Barriers ...................................119

2. Franchisees' Weak Incentive to Support an Association ....... 124

3. Industry Data Support ........................................................... 126

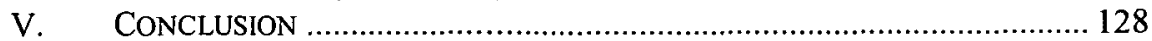

\section{INTRODUCTION}

Franchising plays a vital role in the U.S. economy. There are over 700,000 franchised business establishments. ${ }^{1}$ These establishments

1. IHS Global InSight, Franchise Business ECONOMic OUtLook: May 20121 (2012), available at http://emarket.franchise.org/BusinessOutlookReport2012.pdf. 
provide approximately eight million jobs. ${ }^{2}$ Furthermore, they annually produce goods and services worth more than $\$ 700$ billion, and they contribute more than $\$ 400$ billion to the GDP. ${ }^{3}$ Given the economic magnitude of franchising, it is not surprising that policymakers, legal theoreticians, franchisors, and franchisees have had differences of opinion regarding the desired rights and duties of the parties involved in the franchise industry. In the last few decades, the most vital debate in franchise law has focused on whether state or federal law should protect franchisees against potential opportunistic behavior of franchisors toward franchisees. ${ }^{4}$ This issue is currently being debated in several states. For example, representatives in California have recently introduced a new bill, The Level Playing Field for Small Business Act of 2012, which, if enacted, would provide significant protection for franchisees against franchisor opportunism. ${ }^{5}$ Similarly, a Massachusetts bill, An Act Further Regulating Franchise Agreements, has been introduced recently in an effort to protect franchisees against franchisor opportunism. ${ }^{6}$ Another bill aiming to curb franchisor opportunism was introduced recently in Vermont. ${ }^{7}$ The debate over the desirability of franchisee protection laws

2. Alisa Harrison \& Matthew Haller, Franchise Growth Lags as Fiscal Cliff Threatens Expansion, INT'L FRANCHISE ASS'N (Sept. 10, 2012), http:/www.franchise.org/IFA_NEWS/Franchise_Growth_Lags_As_Fiscal_Cliff_Threate ns_Expansion.

3. IHS GLOBAL INSIGHT, supra note 1.

4. The major types of franchisor opportunistic behavior at which franchisee protection laws are aimed will also be explained in Part III. On the scholarly debate over the desirability of franchisee protection laws, see, for example, RoGER D. BLAIR \& Francine Lafontaine, The Economics of Franchising 233-34 (2005); Roger D. Blair \& Francine Lafontaine, Understanding the Economics of Franchising and the Laws that Regulate It, 26 FRANCHISE L.J. 55, 63 (2006); James A. Brickley et al., The Economic Effects of Franchise Termination Laws, 34 J.L. \& ECON. 101 (1991); Robert W. Emerson \& Uri Benoliel, Are Franchisees Well-Informed: Revisiting the Debate Over Franchise Relationship Laws, 76 ALB. L. REV. 193 (2013); Richard A. Epstein, Unconscionability: A Critical Reappraisal, 18 J.L. \& ECON. 293, 314-15 (1975); David Hess, The Iowa Franchise Act: Towards Protecting Reasonable Expectations of Franchisees and Franchisors, 80 IowA L. REV. 333 (1995); Richard L. Smith II, Franchise Regulation: An Economic Analysis of State Restrictions on Automobile Distribution, 25 J.L. \& ECON. 125 (1982).

5. For text of the new proposed bill, see Assemb. 2305, 2012 Leg., Reg. Sess. (Cal. 2012), available at http://leginfo.legislature.ca.gov/faces/billNavClient.xhtml?bill id= 201120120AB2305. For a brief review of the bill, see Robert Purvin, California Introduces Bill for Fairer Franchising, BLUE MAUMAU (Mar. 6, 2012, 8:02 AM), http:/www.bluemaumau.org/11336/california_drafting_fair_franchising_bill.

6. For text of the new proposed bill, see S. $18 \overline{4} 3, \overline{187}$ th Gen. Court, Reg. Sess. (Mass. 2011), available at http://www.malegislature.gov/Bills/187/Senate/S01843. For a brief explanation of the new bill, see Massachusetts Introduces Franchise Bill!, BuUE

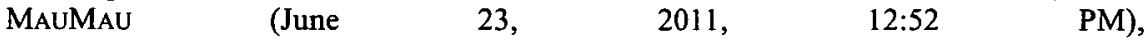
http://www.bluemaumau.org/10467/massachusetts_introduces_franchise_bill.

7. For text of the new proposed bill, see H.R. $694,201 \overline{2}$ Gen. Assemb., Reg. Sess. (Vt. 2012), available at http://www.leg.state.vt.us/docs/2012/bills/Intro/H-694.pdf. 
is global and not limited to the United States. While some countries such as Australia ${ }^{8}$ and China $^{9}$ have decided to enact franchisee protection laws, other countries, such as Japan ${ }^{10}$ and Israel, ${ }^{11}$ have failed to do so.

Within the debate over the desirability of franchisee protection laws, franchisor advocates suggest that such laws are superfluous. ${ }^{12}$ Deeply ingrained in franchisor advocates' opposition to such legislation is the belief that independent franchisee associations, namely trade associations formed by franchisees within a single franchise chain, ${ }^{13}$ serve as a sufficient barrier against franchisor opportunism. ${ }^{14}$ As the late, prolific law and economics scholar Larry Ribstein contended: "The benefits of franchisee-protection laws are unclear. Even without such laws, franchisees can ... coordinate resistance to franchiser opportunism through franchisee associations. . .."15 Similarly, Thomas Pitegoff, a

8. Australia enacted a franchisee protection law called "The Franchising Code of Conduct." See Franchising Code of Conduct 2010 (Cth) (Austl.), available at http://www.comlaw.gov.au/Details/F2010C00457.

9. China enacted a franchisee protection law called "The Regulation on the Administration of Commercial Franchises." See Regulation on the Administration of Commerce (promulgated by the St. Council, Feb. 6, 2007, effective May 1, 2007) (China), available at http://tradeinservices.mofcom.gov.cn/en/b/2007-02-06/23214.shtml.

10. See Etsuko Hara, Japan, in FrANCHISE IN 30 JURISDICTIONS WORLDWIDE 93 (Philip F. Ziedman ed., 2012), available at http://www.amtlaw.com/res/news_2011en_pdf/111024_2449.pdf ("There are no specific laws regulating the ongoing relationship between franchisors and franchisees.").

11. In Israel, franchise contracts are mainly governed by general contract law. See Peggy Sharon \& Inbal Natan-Zehavi, Aspects of Franchising Law in Israel, LeviTAN, SHARON \& Co., http://www.israelinsurancelaw.com/franchise-and-distribution/aspects-offranchising-law-in-i.html (last visited Aug. 16, 2013). On the Israeli debate over the desirability of franchisee protection laws see, for example, Shuki Sade, Trapped in the Net, http://www.haaretz.co.il/misc/1.1212149 (last visited Aug. 16, 2013) (translated from Hebrew to English by authors).

12. See infra Part III.

13. See Michael Einbinder \& Eric H. Karp, So You've Bought Your First Boat: Forming an Independent Franchisee Association ... A Turn-Key Approach 5 (May 4-5, 2000) (unpublished manuscript), available at http://www.ed-lawfirm.com/News-andEvents/First-Boat.pdf. "The governance of [independent franchisee associations] is usually completely free of input from the franchisor. ..." Benjamin Lawrence \& Patrick J. Kaufmann, Identity in Franchise Systems: The Role of Franchisee Associations, $87 \mathrm{~J}$. RETAILING 285, 288 (2011) [hereinafter Lawrence \& Kaufmann, Identity in Franchise Systems], available http://www.sciencedirect.com/science/article/pii/S002243591000093X\#.

14. See infra Part III.

15. Larry E. Ribstein, From Efficiency to Politics in Contractual Choice of Law, 37 Ga. L. Rev. 363, 397 (2003) [hereinafter Ribstein, From Efficiency to Politics]. See also James A. Brickley et al., supra note 4, at 115 (discussing the political strength of franchisee associations); W. John Moore, Franchisees Are Sizzling, NAT'L L.J., Feb. 8, 1992, at 340, 340-41 (discussing how franchisee associations can limit franchisor opportunism). But see Larry E. Ribstein, Choosing Law by Contract, 18 J. CoRP. L. 245, 276 (1993) [hereinafter Ribstein, Choosing Law by Contract] (suggesting that "franchisees within a given state may be more influential than the national franchiser 
member of the legislative committee of the International Franchise Association, argued: "Franchise relationship laws are based on legislative findings of an inequality of bargaining power between franchisors and franchisees, and of abuses by franchisors. . . . In fact, there is far less inequality today between franchisors and franchisees. . . . [F]ranchisee associations are wielding more power than ever." $" 16$

Although organizing into independent franchisee associations may give franchisees "increasing voice and leverage," the idea that independent franchisee associations can substitute for franchisee protection laws. More specifically, this Article argues that in most cases, independent franchisee associations are unlikely to be established in the first place. In short, the argument is as follows: typically, an individual franchisee is unlikely to lead the formation of an independent franchisee association because the franchisee leader's expected costs of leadership exceed her expected benefits. On the expected costs side, the franchisee leader is exposed to harmful retaliation on the part of the franchisor for her role as leader, which may take on the drastic form of contract termination. ${ }^{18}$ The probability of such harmful retaliation is significant given that, as opposed to labor law, which prohibits an employer from retaliating against an employee who forms an association, federal and most state franchise laws do not

organization," but nonetheless have little impact on legislation because legislatures want to create efficient laws that are not harmful to business in the state).

16. Thomas M. Pitegoff, Franchise Relationship Laws: A Minefield for Franchisors, 45 Bus. LAw. 289, 314-15 (1989). See also AM. BAR Ass'N, REPORT OF THE AMERICAN Bar AsSOCIATION SECTION OF ANTITRUSt LaW ON Proposed SMall Business FrANCHISE ACT n.14 (Dec. 13, 1999), available at $\mathrm{http} / / / \mathrm{www}$.americanbar.org/content/dam/aba/administrative/antitrust_law/report_2e0e95 b.authcheckdam.pdf ("More recently, some believe [that the] disparities [of power between franchisors and franchisees] have lessened as the result of . . the advent of franchisee associations. ..."); Carla Wong McMillian, What Will It Take to Get You in a New Car Today?: A Proposal for a New Federal Automobile Dealer Act, 45 GonZ. L. REV. 67, 87 (2010) ("The power of the franchisees is enhanced even further through franchisee associations that often negotiate the terms of these contracts on behalf of large groups of franchisees.").

17. Marc Ballon, Franchisees Organize to Counter Company Power, L.A. TiMEs, Feb. 23, 2000, http://articles.latimes.com/2000/feb/23/business/fi-1625 (quoting Richard Purvin, president of the American Association of Franchisees and Dealers in San Diego, California).

18. See infra Part IV.A.1. Certainly, alleged franchisor retaliation may occur in response to franchisee claims against the franchisor. See, e.g., Duff v. Marathon Petroleum Co., 51 F.3d 741, 743 (7th Cir. 1995) (personal injury); United Consumers Club, Inc. v. Bledsoe, 441 F. Supp. 2d 967, 979 (N.D. Ind. 2006) (breach of contract); Baker v. Amoco Oil Co., 761 F. Supp. 1386, 1392 (E.D. Wis. 1991) (fraud), aff'd, 956 F.2d 639 (7th Cir. 1992); Gilderhus v. Amoco Oil Co., 470 F. Supp. 1302, 1305 (D. Minn. 1979) (breach of contract). However, the focus of this Article is termination as retaliation for franchisee association activities. 
adequately prohibit franchisors from taking retaliatory actions against a leading franchisee. ${ }^{19}$

On the expected benefits side, the probability that the leading franchisee will succeed in forming a sustainable association is very low. ${ }^{20}$ The establishment of an independent franchisee association faces two unique and noteworthy obstacles. First, franchisors often establish, fund, and control a competing franchisee committee, known as a franchisor advisory council, which serves franchisors as a tool to reduce the probability that an independent franchisee association will survive. Specifically, franchisors often refuse to negotiate with the independent franchisee association members once such an association is established, claiming that the franchisees' concerns are addressed through the franchisor advisory council. ${ }^{21}$ Second, franchisees have little incentive to join and actively participate in an independent franchisee association once it is formed because: (1) a franchisee's basic incentive is to freeride on the efforts of other franchisees that will support the independent association; (2) franchisees fear harmful retaliatory actions by the franchisor; and (3) sometimes, franchisees may be enticed by franchisor benefits to refrain from joining the association. ${ }^{22}$

This Article's theoretical argument, that in most cases independent franchisee associations are unlikely to be established in the first place, is backed by industry data that have accumulated over recent years, and which have so far been overlooked in the debate over franchisee protection laws. The industry data reveal that of the approximate 3,000 franchise chains in the United States, only a small percentage of chains have independent franchisee associations. ${ }^{23}$

This Article will proceed as follows: Part II will provide legal context by briefly reviewing the statutory framework underlying the debate over the desirability of franchisee protection laws. Part III will furnish theoretical context by outlining the central argument on which franchisor advocates base their opposition to franchisee protection laws-namely, that franchisee associations can prevent franchisor opportunism. Finally, Part IV will include cost-benefit analysis and industry data while presenting the authors' critique of the franchisor advocates' argument.

\footnotetext{
19. See infra Part IV.A.2.

20. See infra Part IV.B.

21. See infra Part IV.B.1.

22. See infra Part IV.B.2.

23. See infra Part IV.C.
} 


\section{FRANCHISEE PROTECTION LAWS-OVERVIEW}

Franchisee protection laws are statutes that primarily govern the ongoing relationship between franchisors and franchisees. ${ }^{24}$ These laws have two central, alleged purposes: first, to correct a perceived inequality in bargaining power between franchisors and franchisees; ${ }^{25}$ and second, to protect franchisees against perceived franchisor opportunism. ${ }^{26}$ The major types of franchisor opportunistic behavior at which franchisee protection laws are aimed come in several forms. ${ }^{27}$ First, the franchisor may terminate the contract unjustly; specifically, the franchisor may terminate the contract without a material breach by the franchisee to appropriate the profits of the franchisee unit. This termination is accomplished either by operating the outlet directly or selling it to a new franchisee under a contract involving higher fees. ${ }^{28}$ Second, the franchisor may require contractually that any dispute be arbitrated outside the franchisee's state in order to increase franchisee

24. See, e.g., NeB. ReV. STAT. § 87-401 (2011); N.J. Stat. ANN. § 56:10-2 (West 2012); R.I. GEN. LAWS $\S 19-28.1-2$ (2011); VA. CODE ANN. $§ 13.1-558$ (2011); Thomas M. Pitegoff \& W. Michael Garner, Franchise Relationship Laws, in FUNDAMENTALS OF FRANCHISING 183, 184 (Rupert M. Barkoff \& Andrew C. Selden eds., 3d ed. 2008); Hess, supra note 4 , at $346-47$.

25. See, e.g., WIS. STAT. $\S 135.025(2)$ (b) (2011); see also Christopher J. Curran, Claims Against a Franchisor upon an Unreasonable Withholding of Consent to Franchise Transfer, 23 J. CORP. L. 135, 152 (1997); Peter C. Lagarias \& Robert S. Boulter, The Modern Reality of the Controlling Franchisor: The Case for More, Not Less, Franchisee Protections, 29 FranchISE L.J. 139, 141 (2010); Dennis D. Palmer, Franchises: Statutory and Common Law Causes of Action in Missouri Revisited, 62 UMKC L. REV. 471, 491 (1994); Pitegoff, supra note 16, at 289.

26. See, e.g., WIS. STAT. § 135.025(2)(b) (2011); see also Geib v. Amoco Oil Co., 29 F.3d 1050, 1056 (6th Cir. 1994); Bitronics Sales Co. v. Microsemiconductor Corp., 610 F. Supp. 550, 556 (D. Minn. 1985); Hartford Elec. Supply Co. v. Allen-Bradley Co., No. CV 96562061S, 1997 WL 297256, at *3 (Conn. Super. Ct. May 28, 1997), aff'd, 736 A.2d 824 (Conn. 1999); Holiday Inns Franchising, Inc. v. Branstad, 537 N.W.2d 724, 728-29 (lowa 1995); McDonald's Corp. v. Markim, Inc., 306 N.W.2d 158, 162 (Neb. 1981); Kubis \& Perszyk Assocs. v. Sun Microsystems, Inc., 680 A.2d 618, 626 (N.J. 1996); David L. Cahn \& Jeffrey S. Fabian, Mobility, the Home, and the Scope and Application of State Franchise Relationship and Termination Laws, 30 FRANCHISE L.J. 107, 107 (2010); Curran, supra note 25, at 152; Palmer, supra note 25, at 491; Pitegoff, supra note 16, at 289.

27. See Lagarias \& Boulter, supra note 25, at 143-44; Pitegoff \& Garner, supra note 24, at 187-88; Pitegoff, supra note 16, at 329-31.

28. A number of states have laws dealing with the rights and responsibilities related to franchise terminations. See, e.g., ARK. CODE ANN. § 4-72-209 (2011); CAL. BUS. \& Prof. CodE $\S \S 20020-21$ (West 2011); HaW. ReV. StaT. § 482E-6(H) (2011); 815 Ill. COMP. STAT. 705/19 (2011); IOWA CODE §§ 523H.7(1), 537A.10(7)(c) (2011); MINN. StaT. $\S 80$ C.14(3)(b) (2011); Miss. Code ANN. § 75-24-57 (2011); Mo. ANN. STat. $\S 407.405$ (1) (West 2011); Neb. REV. STAT. § 87-404 (2011); N.J. STAT. ANN. § 56:10-5 (West 2012); N.D. CENT. CODE $\S 51-20.2$ (2011); P.R. LAWS ANN. tit. 10, § 278a (2011); R.I. GEN. LAWS § 6-50-4 (2011); WASH. REV. CODE § 19.100.180(2)(j) (2011); WIS. STAT. § 135.03 (2011). 
litigation costs, thereby deterring her from suing the franchisor. ${ }^{29}$ Third, the franchisor may encroach on the franchisee's territory, namely by establishing a new franchise unit in unreasonable proximity to an existing franchisee, dramatically reducing the franchisee's profitability and thereby causing her to abandon the chain. ${ }^{30}$

To date, only a minority of states has enacted general franchisee protection laws aiming to curb franchisor opportunism. ${ }^{31}$ At the federal level, several general franchise relationship bills have been introduced, but all have been rejected. ${ }^{32}$ For example, a federal franchise relationship law of general application was proposed in 1971, but it was

29. For examples of laws prohibiting this practice, see CAL. BUS. \& PrOF. CODE $\S 20040.5$ (West 2011); MICH. COMP. LAWS § 445.1573 (2011); MNN. STAT. § 80C.21 (2011); R.I. GEN. LAWS § 19-28.1-14 (2011).

30. States have also passed laws prohibiting this practice. See, e.g., HaW. REV. STAT. $\S$ 482E-6(2)(E) (2011); IND. CODE $\S$ 23-2-2.7-1(2), (9) (2011); IOWA CODE $\S 523$ H.6(1) (2013); MINN. R. 2860.4400(C) (2011); WASH. REV. CODE $\S 19.100 .180(2)(\mathrm{f})(2011)$. Such an encroachment strategy is sometimes used by franchisors in order to achieve one central hidden objective: to evade a contractual or statutory obligation to pay damages to a franchisee upon contract termination. See Michael Garner, A Termination by Any Other Name, BLuE MAUMAU (Feb. 14, 2008, 5:22 $\mathrm{PM})$, http://www.bluemaumau.org/a_termination_by_any_other_name. Instead of formally and directly terminating the franchise contract-a behavior that may expose the franchisor to an obligation to pay damages to the terminated franchisee-franchisors use an encroachment strategy. Id. This strategy "erode[s] [the] franchisee's business to the extent that it is no longer viable, causing the franchisee to [surrender the business]." Id. Thus, encroachment allows "the franchisor [to] accomplish[] indirectly what it might not be able to accomplish lawfully through a direct termination." Id. Similarly, some franchisors use an encroachment strategy in order to reduce the profitability of their franchisees' units, such that the units eventually will be less expensive for the franchisor to repurchase from the franchisee. See, e.g., Photovest Corp. v. Fotomat Corp., 606 F.2d 704, 719 (7th Cir. 1979). For more on the subject, see Robert W. Emerson, Franchise Encroachment, 47 AM. BUs. L.J. 191 (2010).

31. See, e.g., ARK. CODE ANN. §§ 4-72-201 to -210 (2007); CAL. Bus. \& Prof. CodE $\S \S 20000-10$ (West 2005); DEL. CODE ANN. tit. 6, $\S \S 2551-56$ (2005); HAW. REV. STAT. $\S 482 \mathrm{E}-1$ to -11 (2007); 815 ILL. COMP. STAT. 705/1 to /11 (2009); IND. CODE $\S \S 23-2$ 2.5-1 to -51 (2008); IoWA CODE ANN. §§ 523H.1-.17 (West 2007); MICH. CoMP. LAWS ANN. $\S \S 445.1501-.1546$ (West 2005); MINN. STAT. ANN. $\S \S 80$ C.01-.30 (West 2006); Neb. REV. STAT. $\S \S 87-401$ to -410 (2006); N.J. STAT. ANN. $\S \S 56: 10-1$ to -15 (West 2012); S.D. CoDIFIED LAWS $\S \S 37-5$ A-1 to -87 (2006) (repealed 2008), available at http://law.justia.com/codes/south-dakota/2006/37/37-5a.html; TENN. CODE ANN. §§ 4725-1501 to -1511 (2006); VA. CODE ANN. \$§ 13.1-557 to-574 (2002); WASH. REV. CODE $\S \S 19.100 .010-.940$ (2007); Wis. STAT. ANN. $\S \S 135.01-.07$ (West 2006). The District of Columbia, Puerto Rico, and the Virgin Islands also have franchisee protection laws. See D.C. CODE § 34-1731.06 (2013); P.R. LAWS ANN. tit. 10, §§ 278-278d (2006); V.I. CODE ANN. tit. 12A, $\S \S 130-39$ (2004).

32. See, e.g., Ernest A. Braun, Policy Issues of Franchising, 14 Sw. U. L. REv. 155, 203-04 (1984); Robert W. Emerson, Franchise Terminations: Legal Rights and Practical Effects When Franchisees Claim the Franchisor Discriminates, 35 AM. Bus. L.J. 559, 562-63 (1998); Donald P. Horwitz \& Walter M. Volpi, Regulating the Franchise Relationship, 54 ST. JOHN's L. REV. 217, 218 (1980). 
not enacted. ${ }^{33}$ In 1992, former Democratic Congressman James H. Scheuer introduced a franchise relationship bill that was also not passed. ${ }^{34}$ Similarly, former Democratic Congressman John J. LaFalce in 1993 and 1995, and Republican Congressman Howard Coble in 1998 and 1999, each proposed franchise relationship bills that did not pass. ${ }^{35}$ In addition, in 2007, the Federal Trade Commission considered, but eventually rejected, federal regulation of the franchise relationship. ${ }^{36}$

\section{THE FRANCHISOR ADVOCATES' VIEW}

Franchisor advocates suggest that franchisees do not need special protection laws to provide legal protection against franchisor opportunism. Essential to the resistance against franchisee protection laws is the argument that independent franchisee associations can function as a substitute for legislation. ${ }^{37}$ Franchisor advocates argue that the benefits of franchisee protection laws are unclear because franchisees can coordinate resistance to franchisor opportunism through franchisee associations, even without such laws. ${ }^{38}$ In particular, franchisor advocates suggest that by collectivizing a large percentage of the franchisees in the franchise system, independent franchisee associations improve the bargaining position of franchisees. ${ }^{39}$ The assumption made by franchisor advocates is that the association's collective leverage places the association at a strong advantage in negotiations with the

33. Pitegoff \& Garner, supra note 24 , at 185.

34. See Federal Fair Franchising Practices Act of 1992, H.R. 5961, 102nd Cong. (1992).

35. See Small Business Franchise Act of 1999, H.R. 3308, 106th Cong. (1999); Small Business Franchise Act of 1998, H.R. 4841, 105th Cong. (1998); Federal Fair Franchise Practices Act, H.R. 1717, 104th Cong. (1995); Federal Fair Franchise Practices Act, H.R. 1316, 103d Cong. (1993).

36. Pitegoff \& Garner, supra note 24 , at 186.

37. See Pitegoff, supra note 16, at 314-16; Ribstein, From Efficiency to Politics, supra note 15, at 397; Mary deLeo, Note; Emasculating Goliath: Did Postal Instant Press v. Sealy Strike an Unfair Blow at the Franchising Industry?, 25 W. ST. U. L. REV. 117, 163 n.279, 172 (1997). See also Ann Hurwitz \& Rochelle B. Spandorf, Introduction to Bullding Franchise Relationships: A Guide to anticipating Problems, Resolving CONFlicts, and Representing Clients xxiii, xxiii-xxiv (Ann Hurwitz \& Rochelle Buchsbaum Spandorf eds., 1996).

38. See Ribstein, From Efficiency to Politics, supra note 15, at 397. See also Scott McIntosh, Fair Criticism, Cyberlibel, and Unlawful Coordinated Action over the Internet, 20 FRANCHISE L.J. 181, 181-82 (2001) (suggesting that the free flow of communication via the internet will stimulate both formal and informal franchise associations).

39. See Deborah S. Coldwell, Initial Pleadings, in FranchISE LITIGATION HANDBOOK 1, 2 (Dennis LaFiura \& C. Griffith Towle eds., 2010) ("A franchisor is more likely to find a reasonable solution when confronted by a large franchisee group."). 
franchisor regarding the franchise contract terms. ${ }^{40}$ As a result, the association is presumed to be successful in negotiating contract terms that protect franchisees from franchisor opportunism, eliminating the need for franchisee protection laws. As Thomas Pitegoff suggests, "franchisee associations ensure that the entire franchise system is fair, thereby protecting the newcomers among the franchisees." 41

\section{THE CRITIQUE}

The franchisor advocates' argument that independent franchisee associations serve as a substitute for franchisee protection laws rests on

40. See McMillian, supra note 16, at 87 ("The power of the franchisees is enhanced even further through franchisee associations that often negotiate the terms of these contracts on behalf of large groups of franchisees."); deLeo, supra note 37, at 264 n.279 ("Much debate, however, has centered around the question of whether these franchise relationship statutes are still necessary today. The recent emergence of strong, sophisticated franchisees, coupled with the advent of franchisee associations, has led to a realignment of power in some franchise systems, and the 'take it or leave it' attitudes typical of franchisors in the 1970's and 1980's are giving way as franchisors become increasingly sensitive to the collective power of their franchisees."). See also Nicholas Argyres \& Janet Bercovitz, The Impacts of Efficiency and Bargaining Power on Contract Structure: Evidence from Franchising 13 (Feb. 16, 2010) (unpublished manuscript), available at http://ssrn.com/abstract $=1554037$ ("[I]ndependent franchisee associations appear to be formed with the primary purpose of gaining negotiating leverage").

41. Pitegoff, supra note 16 , at 316 ; see also Coldwell, supra note 39 , at 2 ("Systemwide change through litigation can be expensive to resolve ... [and] more likely to provoke a vigorous defense from the franchisor. Thus . . . a franchisee attempting to modify a systemwide issue may consider joining forces with other franchisees or pursuing litigation through a franchisee association."); Benjamin Lawrence \& Patrick J. Kaufmann, Franchisee Associations: Strategic Focus or Response to Franchisor Opportunism, 17 J. MARKETING CHANNELS 137, 138 (2010) [hereinafter Lawrence \& Kaufmann, Franchisee Associations] ("In [independent franchisee associations], franchisees band together into a cohesive unit that often wields sufficient countervailing power to ensure that they receive a fair deal from their franchisors."); Ribstein, Choosing Law by Contract, supra note 15, at 259 ("[F]ranchisees, rather than being helpless, can effectively coordinate resistance to opportunism by franchisers by forming franchisee associations."). However, when an association is formed, some franchisors are suddenly hostile to the idea, regarding associations as "confrontation[al]." See RICHARD L. Kolman \& HaRris J. Chernow, FranChISEE ASSOCIATIONS AND FranCHISE ADVISORY COUNCILS ("FAC"): A REVIEW OF THE FUNDAMENTALS AND ANNOTATED BIBLIOGRAPHY OF HELPFUL RESOURCES 9 (2007), available at http://kfcog.weebly.com/uploads/1/3/9/7/13973429/franchisee_assoc_ifas_and_facs_whit epaper.pdf. It seems franchise associations are often born out of discontent with a franchisor or FAC, which supports the assumption that franchisors see associations as hostile entities. See Roger Schmidt, SR. \& Harris J. Chernow, Managng the ORGANIZATION OF A FRANCHISE Association 3 (2009), available at http://www.americanbar.org/groups/franchising/events_cle/past_program_materials.html; JOSEPH SCHUMACHER, WILLIAM DARRIN \& LAWRENCE COHEN, EFFECTIVE RELATIONSHIPS WITH FRANCHISEE ASSOCIATIONS: LEGAL AND PRACTICAL ASPECTS 4 (2001), available at http://www.wiggin.com/files/Effective $\% 20$ Relationships $\% 20$ with $\% 20$ Franchisee $\% 20$ Ass ociations.pdf. 
an implicit assumption that such associations exist, or, that such associations at least have the potential to exist, in most chains. This assumption, however, is dubious. In most cases, independent franchisee associations are unlikely to be established because the expected costs of forming an association typically exceed the expected benefits for individual franchisees considering whether or not to establish an association. $^{42}$

\section{A. High Expected Costs for Franchisee Association Leader}

The expected costs of forming an independent franchisee association are high due to two central cumulative reasons. ${ }^{43}$ First, the franchisor may decide to retaliate against the leading franchisee if he or she establishes, or attempts to establish, an association, thus causing the franchisee significant harm. ${ }^{44}$ Second, the probability that the franchisor will retaliate against the leading franchisee is significant. ${ }^{45}$

\section{High Retaliation Costs}

Harmful retaliation by franchisors against association leaders may take several forms. For example, a franchisor may not renew the contract with the franchisee association leader, ${ }^{46}$ or the franchisor may elect not to allow the leader to open new units in the franchise chain. ${ }^{47}$

42. Also, many franchisee associations ultimately fail, even if they are initially supported by the franchisor. See SCHMIDT \& CHERNow, supra note 41, at 10 .

43. By "costs," the authors are referring to the potential consequences to a franchisee for establishing an independent franchisee association. Interestingly, the monetary startup costs for establishing an independent franchisee association are actually quite low, usually "limited to [the cost of] hiring a lawyer to create a corporation or legal entity and the costs of the initial membership drive." Forming an Independent Franchisee Association, SINGLER \& DILLON, LLP, http://www.singler-law.com/guides/ association.html (last visited Aug. 16, 2013). These start-up costs are usually divided among the organizers equally or based on the size of the franchisee. Id. If the association attracts members, the start-up costs may be repaid through membership dues. Id. In California, the cost to hire a lawyer to create a corporation or legal entity ranges between $\$ 1100$ and $\$ 1500$. See California Incorporation/Corporations, LAW OFFICE OF JONAS M. GRANT, A.P.C., http://www.incorporatecalifornia.com/corporations.html (last visited Aug. 16, 2013).

44. See infra Part IV.A.1.

45. See infra Part IV.A.2.

46. See Russell M. Knight, The Role of Franchisee Associations, 3 CAN. J. AdmIN. SCI. 114, 119 (1986) (noting that McDonald's allegedly punished franchisees by not renewing their franchises).

47. See Dunafon v. Taco Bell Corp., No. 93-4490-CV-C-9, 1996 U.S. Dist. LEXIS 22026, at *5 (W.D. Mo. Mar. 13, 1996) (recounting instance in which the franchisor publicly stated that the leaders of the franchisee association would not be granted expansion rights within the franchisor system); STAN LuXENBERG, ROADSIDE EMPIRES 270 (1985) (noting that Taco Bell moved to oppose an association that franchisees were 
In another common practice, a franchisor may withhold consent to the association leader's request to transfer her franchisee unit to a third party, ${ }^{48}$ or the franchisor may simply schedule excessive inspections for the association leader. ${ }^{49}$ Most dramatically, franchisors may terminate the franchise contract with the franchisee association leader. ${ }^{50}$ Such harsh retaliatory action entails significant costs on the part of the association leader. These costs mainly include, as will be explained below in more detail, loss of relationship-specific investments. ${ }^{51}$

Relationship-specific investments, also known as idiosyncratic investments, are investments specific to a concrete franchise relationship. ${ }^{52}$ They are highly specialized and tailored to that franchise relationship $^{53}$ and, as such, are difficult or impossible to redeploy to

forming and dropped hints to franchisees that troublemakers may not be permitted to open additional units); Knight, supra note 46, at 119 (stating that McDonald's allegedly harassed the franchisees by not allowing them to open new units).

48. See Popeyes, Inc. v. Tokita, Civ. A. Nos. 87-3011, 90-1179, 1993 U.S. Dist. LEXIS 13295, at *32-33 (E.D. La. Sept. 21, 1993) (finding that the franchisor unreasonably withheld written consent to transfer the franchisee's unit to other franchisees to retaliate for the franchisee's activities in a franchisee association).

49. See Pepperidge Farm, Inc. v. Mack, Bus. Franchise Guide (CCH) ๆ 9530 (S.D. Cal. Nov. 29, 1989) (relating how the franchisor surveyed and photographed the unit of a franchisee who was a leader of a franchisee association); Knight, supra note 46, at 119 (describing how McDonald's allegedly harassed the franchisee with frequent visits from quality control inspectors who cite the operator for small infractions); Joseph Schumacher et al., Effective Relationships with Franchisee Associations--Legal and Practical Aspects 32 (May 6-8, 2001) (unpublished manuscript), available at http://www.franchise.org/files/Effective $\% 20$ Relationships $\% 20$ With $\% 20$ Franchisee $\% 20 \mathrm{~A}$ ssoc.PDF.

50. See, e.g., Bray v. QFA Royalties LLC, 486 F. Supp. 2d 1237, 1239 (D. Colo. 2007) (recounting instance in which the franchisor sent letters terminating the franchise rights of all of the franchisee association board members); Cherick Distribs., Inc. v. Polar Corp., 669 N.E.2d 218, 220 (Mass. App. Ct. 1996) (detailing the franchisor's termination of its agreement with a franchisee upon discovering that the franchisee had written a letter to other franchisees urging them to attend a meeting to discuss the possibility of forming a franchisee association); Pepperidge Farm, Bus. Franchise Guide (CCH) 99530 at 9530 (describing the franchisor's termination of the franchisee for the latter's leadership role in a franchisee association); ROBERT L. PURVIN, JR., THE Franchise FRAUD 211 (2008) (noting that McDonald's punished the association leaders by terminating their franchises); Knight, supra note 46, at 119.

51. The following explanation is based on Uri Benoliel, Rethinking the U.S. Supreme Court's Abandonment Requirement in Mac's Shell Service Inc. v. Shell Oil Products, 43 RUTGERS L.J. 77, 83-86 (2011).

52. See Erin Anderson \& Barton Weitz, The Use of Pledges to Build and Sustain Commitment in Distribution Channels, 29 J. MARKETING RES. 18, 20 (1992).

53. See Shankar Ganesan, Determinants of Long-Term Orientation in Buyer-Seller Relationships, 58 J. MARKETING 1, 6 (1994); Jan B. Heide \& George John, The Role of Dependence Balancing in Safeguarding Transaction-Specific Assets in Conventional Channels, 52 J. MARKETING 20, 21 n.1 (1988). 
another relationship. ${ }^{54}$ Therefore, they have little or no salvage value to a franchisee association leader once the franchisor terminates her contract. $^{55}$ Relationship-specific investments include leasehold improvements, namely fixtures that are attached to the retail or commercial space and installed by the franchisee when setting up a new location. ${ }^{56}$ Examples of such improvements include walls, doors, cabinets, light fixtures, and floor coverings. ${ }^{57}$ Such improvements may be significant. For example, a Subway franchisee may be required to invest up to $\$ 130,000$ in leasehold improvements. ${ }^{58}$

Leasehold improvements are often relationship-specific investments, which are lost if the franchisor terminates the contract with the association leader. This loss is incurred because franchisors often require the franchisee to lease, rather than own, the land upon which the outlet is located. ${ }^{59}$ The lease arrangement grants the franchisor the right to require the franchisee to evacuate the leased property upon termination of the franchise. ${ }^{60}$ As a result, the leasehold improvements, which remain the property of the franchisor, must be surrendered by the franchisee along with the property, causing the franchisee significant economic loss. ${ }^{61}$

Equipment expenditures are another form of relationship-specific investment lost by an association leader if the franchise agreement is terminated by a retaliating franchisor. Depending upon the conditions of n.1.

54. See Anderson \& Weitz, supra note 52, at 20; Heide \& John, supra note 53, at 21

55. Cf. James R. Brown et al., The Effects of Transaction-Specific Investments in Marketing Channels: The Moderating Role of Relational Norms, 17 J. MARKETING THEORY \& PRAC. 317, 317 (2009) ("Transaction-specific investments . . . have little or no value outside of that relationship."); Ganesan, supra note 53, at 6 ("Transaction-specific assets are investments in durable assets that are ... not easily redeployable and have little salvage value in other relationships."); Jan B. Heide \& George John, Alliances in Industrial Purchasing: The Determinants of Joint Action in Buyer-Supplier Relationships, 27 J. MARKETING RES. 24, 27 (1990) ("Specific investments are investments made by a firm that are of considerably less value outside the focal relationship.").

56. See Franchise Tutorial 20: Intro to Leasehold Improvements, CAN. FRANCHISE Ass'N (Jan. 2011), http://www.cfa.ca/Publications_Research/Tutorials/tutorial20.aspx.

57. Id.

58. See

Subway,

FRANCHISE

DIRECT, http://www.franchisedirect.com/directory/subway/ufoc/915 (last visited Aug. 16, 2013).

59. See ANNe T. Coughlan et al., Marketing Channels 539 (7th ed. 2006); Benjamin Klein, Transaction Cost Determinants of "Unfair" Contractual Arrangements, 70 AM. ECON. REV. 356, 359 (1980).

60. See Klein, supra note 59, at 359.

61. Antony W. Dnes, 'Unfair' Contractual Practices and Hostages in Franchise Contracts, 148 J. INST. \& THEORETICAL ECON. 484, 487 (1992) ("Tenants normally make alterations to commercial premises (leasehold improvements) which must be given up with the property. If the franchisor fails to renew the lease the franchisee cannot adapt improvements to other uses."). 
the space and the particular business model, the required equipment expenditures can be extensive. For example, a McDonald's franchisee may be required to invest more than one million dollars in equipment, including signs, seating, and décor. ${ }^{62}$ Frequently, much of the equipment purchased cannot be used outside the franchise and, thus, the expenditure is relationship-specific. ${ }^{63}$ For example, the fast-food franchisee's outdoor signs cannot be used by the franchisee with any other franchisor. ${ }^{64}$ Similarly, franchise-specific décor is regarded as worthless outside the franchisee's chain. ${ }^{65}$ As a result, if the franchisor terminates the contract with a franchisee association leader, the latter's specialized equipment must be resold at a substantial loss. ${ }^{66}$

\section{High Probability of Retaliation}

The probability that the franchisor will retaliate against a franchisee association is high because the franchisor's expected benefits from retaliation are significant, ${ }^{67}$ and because the franchisor's expected costs of retaliation are relatively low. ${ }^{68}$ Normally, the franchisor will not view the association as a positive development and will strive to eliminate it. ${ }^{69}$ Generally, it is against the franchisor's interest to allow franchisees to benefit from the collective sharing of information that an association can facilitate. ${ }^{70}$ In addition, franchisors endeavor to prevent franchisees from gaining collective bargaining power. ${ }^{71}$ By preventing the establishment of an association, franchisors seek to maintain, and effectively exploit,

\footnotetext{
62. See McDonald's, FRANCHISE DIRECT, http://www.franchisedirect.com/foodfranchises/mcdonalds-franchise-07030/ufoc/ (last visited Aug. 16, 2013).

63. See, e.g., Antony W. Dnes, A Case-Study Analysis of Franchise Contracts, $22 \mathrm{~J}$. LEGAL STUD. 367, 379-80 (1993).

64. See Brown et al., supra note 55, at 317.

65. See Dnes, supra note 63 , at 378 . The secondhand value of trademarked franchise equipment is normally one quarter of its original cost. See Coughlan ET AL., supra note 59, at 537; Dnes, supra note 63, at 378.

66. Cf. Coughlan ET AL., supra note 59, at 537; Dnes, supra note 63, at 377-78; Warren S. Grimes, Making Sense of State Oil Co. v. Khan: Vertical Maximum Price Fixing Under a Rule of Reason, 66 ANTITRUST L.J. 567, 586 (1997); Warren S. Grimes, Market Definition in Franchise Antitrust Claims: Relational Market Power and the Franchisor's Conflict of Interest, 67 ANTITRUST L.J. 243, 250-51 (1999).

67. See infra notes 69-75 and accompanying text.

68. See infra notes 76-112 and accompanying text.

69. See SCHMIDT \& CHERNOw, supra note 41 , at 8 (stating that as few as three companies successfully initiated the process of creating an independent franchisee association); Ballon, supra note 17; Forming an Independent Franchisee Association, supra note 43.

70. See Eric H. Karp, "Comments Concerning the Notice of Proposed Rulemaking Issued by the Federal Trade Commission of October 15, 1999" (Dec. 21, 1999), available at http://www.ftc.gov/bcp/rulemaking/franchise/comments/comment024.htm.

71. See Einbinder \& Karp, supra note 13, at 6.
} 
the gross imbalance of legal and financial power in the franchisorfranchisee relationship. $^{72}$

A franchisor's retaliatory actions against the leading franchisee can do far more than just punish an individual "malcontent;" they may produce three systemic benefits for the franchisor. First, placing pressure on franchisee association leaders may distract those franchisees from devoting time and attention to the association's activities. ${ }^{73}$ Second, retaliatory actions against franchisee leaders dissuade other franchisees from participating in the association, thus further reducing the association's effectiveness. ${ }^{74}$ The message sent by such retaliation to the franchisees in the chain, as a whole, is that support to the independent franchisee association carries with it high costs, including the very real risk that one's franchise contract could be terminated. ${ }^{75}$ Third, retaliatory actions against franchisee leaders are likely to discourage potential leaders from establishing future associations.

The franchisor's expected costs of retaliation are relatively low because federal and most state laws do not sufficiently prohibit franchisors from taking retaliatory actions against leading franchisees. To date, there is no general federal law that prohibits franchisors from taking such actions. ${ }^{76}$ This legal reality stands in direct contrast to the legal regime under federal labor law, which prohibits employers from

72. See id. at 7.

73. See David C. Gurnick \& Les Wharton, Effective Franchisee Associations, Advisory Boards and Councils 12 (Oct. 18-20, 2000) (unpublished manuscript) (on file with authors).

74. Cherick Distribs., Inc. v. Polar Corp., 669 N.E.2d 218, 220 (Mass. App. Ct. 1996) (finding that the franchisor retaliated against a franchisee who was an organizer of a franchisee association in order to discourage other franchisees from participating in the association); Pepperidge Farm, Inc. v. Mack, Bus. Franchise Guide (CCH) I 9530 at 9530 (S.D. Cal. Nov. 29, 1989) (stating that the franchisor took retaliatory actions against a franchisee who participated in a franchisee association in order to deter other franchisees from participating in the franchisee association).

75. Cf. Benjamin I. Sachs, Enabling Employee Choice: A Structural Approach to the Rules of Union Organizing, 123 HARV. L. REV. 655, 687 (2010) (providing a similar argument in the field of employment law).

76. See Robert W. Emerson, Franchising and the Collective Rights of Franchisees, 43 VAND. L. REv. 1503, 1520 (1990); cf. Paul Steinberg \& Gerald Lescatre, Beguiling Heresy: Regulating the Franchise Relationship, 109 PENN. ST. L. REV. 105, 121-22 (2004). Relatedly, Steinberg and Lescatre explain:

Franchisors have the resources to make an example of those who would challenge their interests. By accessing the labor and capital markets with a franchise business model, franchisors are able to achieve freedom from statutes which would otherwise protect workers and investors. Franchisees have far more to lose than hourly employees, and it is not surprising that so many franchisees are reluctant to join associations; the American Franchisee Association has an "Anonymous" membership category for franchisees fearing retaliation. 
taking retaliatory actions against leaders of labor unions. ${ }^{77}$ Not only is there no federal general franchise law that prohibits franchisors from taking retaliatory actions against leading franchisees, but also the two federal industry-specific statutes expressly geared toward franchising do not prohibit such actions. ${ }^{78}$ First, the Automobile Dealer Franchise Act, ${ }^{79}$ commonly known as the Automobile Dealer's Day in Court Act, which sets forth procedures that automobile franchisors must follow during, and at the end of, a franchise contract, does not prohibit retaliation. ${ }^{80}$ Similarly, the Petroleum Marketing Practices Act, ${ }^{81}$ which sets forth procedures that a gas station franchisor must follow before it may terminate or refuse to renew a franchisee, does not prohibit retaliation. $^{82}$

In addition, state law does not sufficiently prohibit franchisors from retaliating against leading franchisees. ${ }^{83}$ Most states have yet to enact statutes that protect a franchisee's right to establish a franchisee association. In fact, only 11 states have enacted general statutes, i.e., statutes that are not restricted to particular industries and that-to varying degrees_protect a franchisee's right to form an association. ${ }^{84}$ However, even in these states, franchisees are not explicitly and unequivocally protected from franchisor retaliation. State statutes are often too mildly worded, ${ }^{85}$ and the franchisor conduct prohibited under these statutes is often defined narrowly. To illustrate, the relevant Michigan statute voids any provision in a franchise contract that would prohibit a franchisee from joining an association, but it does not explicitly provide any protection to franchisee leaders from retaliation in

77. See National Labor Relations Act, 29 U.S.C. $\S \S 157,158(a)(1)$ (2006).

78. See Emerson, supra note 76, at 1520.

79. Automobile Dealer Franchise Act, 15 U.S.C. $\S \S 1221-25$ (2006).

80. See id.

81. Petroleum Marketing Practices Act, 15 U.S.C. $\S \S 2801-06,2821-24,2841$ (2006 \& Supp. V 2012).

82. See id.

83. See, e.g., Peter Lagarias, A Technical Look at Why California's Franchising Abuse Laws Need an Update, Blue MauMaU (Apr. 18, 2012, 10:50 PM), http://www.bluemaumau.org/technical_look_why_california\%E2\%80\%99s_franchise_la w_insufficient (stating that California's franchisee protections should do more to proscribe unfair franchisor practices, such as interference with franchisees' right of association).

84. The following states formally protect that right of franchisees to freely associate: Arkansas, California, Hawaii, Illinois, lowa, Michigan, Minnesota, Nebraska, New Jersey, Rhode Island, and Washington. See ARK. CODE ANN. § 4-72-206 (2011); CAL. CORP. CODE $\S 31220$ (West 2011); HAW. REV. STAT. $\S 482 \mathrm{E}-6$ (2011); 815 Ill. COMP. STAT. 705/17 (2011); IOWA CODE § 523H.9 (2011); MiCH. COMP. LAWS. § 445.1527 (2004); MINN. R. 2860.440 (2011); Neb. ReV. STAT. § 53-216 (2011); N.J. STAT. ANN. § 56:10-7 (West 2012); R.I. GEN. LAWS § 16-21.1-19 (2011); WASH. REV. CODE $\S 19.100 .180(2011)$.

85. See Emerson, supra note 76, at 1505. 
the course of the franchisor-franchisee relationship. ${ }^{86}$ Several commentators have contended that many franchisee association statutes accomplish very little because they merely invalidate "yellow dog" provisions in franchise contracts. ${ }^{87}$ In other words, these statutes only ban franchise agreements that prohibit franchisees from joining franchise associations. They do not, however, make it explicitly unlawful for a franchisor to retaliate against a franchisee for establishing an association. In similar statutes, such as those in Hawaii and Washington, it is unlawful for a franchisor to restrict a franchisee from joining an association, but they do not explicitly prohibit the franchisor from retaliating against a franchisee that has established an association. ${ }^{88}$ In contrast to these states and others that do not have an explicit prohibition against retaliation, ${ }^{89}$ Iowa and Rhode Island explicitly make it unlawful for a franchisor to retaliate against a franchisee for participating in an association. $^{90}$ Finally, although several states have industry-specific statutes that deal with franchisees' rights of association, these statutes cover only a minority of franchise industries, usually the motor vehicles, gasoline, brewery, and winery industries. ${ }^{91}$

In addition to the lack of adequate statutory prohibition of retaliation, the franchisor's expected costs of retaliation are relatively

86. See Мich. СомP. Laws $\S 445.1527$ (2004); see also Mark J. Burzych et al., Discriminatory Treatment of Franchisees 31 (Oct. 6-8, 2004) (unpublished manuscript) (on file with authors).

87. See Emerson, supra note 76, at 1556. "“Yellow dog' contracts were employment agreements in which the employee agreed not to join a labor union." Id. at $1556 \mathrm{n} .255$ (citations omitted).

88. See HAW. Rev. Stat. § 482E-6 (2003); WASH. REV. CODE $§ 19.100 .180$ (2004).

89. See HAW. REV. STAT. § 482E-6 (2003); WASH. REV. CODE $§ 19.100 .180$ (2004).

90. See IOWA CODE ANN. § 523H.9 (West 2011); R.I. GEN. LAWS § 19-28.1-16 (2011). Is a franchisee that establishes a franchise association also, by definition, participating in the association? In lowa and Rhode Island, how does the law treat a franchisee that establishes an association but then chooses not to participate in its activities? There are no reported regulations or cases on these matters.

91. See, e.g., ALA. CODE § 8-20-10 (1988) (motor vehicle dealers); ARIz. REv. STAT. ANN. § 44-1554(1) (1987) (gasoline dealers); CAL. VeH. CODE § 11713.3(n) (West 1987) (motor vehicle dealers); ConN. GEN. STAT. ANN. § 42-133cc(7) (West 1987) (motor vehicle dealers); ConN. GeN. STAT. ANN. § 42-133(f)(2) (West 1987) (petroleum product franchisees); DEL. CODE ANN. tit. 6, § 4913(b)(6) (2005) (motor vehicle franchisees); FLA. STAT. ANN. § 563.022(5)(b)(10) (West Supp. 1990) (beer manufacturers or distributors); GA. CODE ANN. $\S 10-1-662(\mathrm{a})(8)$ (Supp. 1990) (motor vehicle dealers); IDAHO CODE ANN. § 49-1613(3)(f) (1988) (motor vehicle dealers); KY. REV. STAT. ANN. $\S 190.070(2)(\mathrm{h})$ (LexisNexis 1989) (motor vehicle dealers); ME. REV. STAT. ANN. tit. 10, $\S 1180$ (1980) (automobile dealers); MASs. GEN. LAWS ANN. ch. 93B, $\S 10$ (West 1984) (motor vehicle franchisees); MINN. STAT. ANN. § 80E.13(g) (West 1986 \& Supp. 1990) (motor vehicle dealers); VA. CODE ANN. § 4-118.59 (Supp. 1990) (wineries or wine wholesalers); VA. CODE ANN. § 4-118.19 (1988) (breweries or beer wholesalers). For a review of industry-specific statutes that protect the right of franchisees to associate, see Burzych et al., supra note 86, at 32-33, 46-49. 
low due to difficulties of proof often related to the franchisor's high level of discretionary power. Even if franchisor retaliation is prohibited in some states, ${ }^{92}$ for example, under the common-law covenant of good faith and fair dealing, ${ }^{93}$ franchisees generally will find it difficult to prove that retaliation has taken place. ${ }^{94}$ The difficulty in proving retaliation is derived from the discretionary nature of franchisor decision-making under the franchise contract. Franchise agreements frequently give broad discretion to the franchisor. ${ }^{95}$ For example, franchise contracts often contain language reserving a franchisor's discretion to open a competing franchise unit in close proximity to an existing franchisee. ${ }^{96}$ The franchisor may also retain discretion regarding where to place and how to allocate the franchise advertisements. ${ }^{97}$ In

92. Arkansas, California, Hawaii, Illinois, Iowa, Michigan, Minnesota, Nebraska, New Jersey, Rhode Island, and Washington have enacted legislation making it unlawful for a franchisor to retaliate against franchisees for participating in independent association activities. See ARK. CODE ANN. § 4-72-206 (2011); CAL. CORP. CODE $\S 31220$ (West 2011); HaW. Rev. STAT. § 482E-6 (2003); 815 Ill. CoMP. Stat. 705/17 (2011); IOWA CODE ANN. § 523H.9 (West 2011); Mich. COMP. LAWS ANN. § 445.1527 (West 2004); MinN. R. 2860.440 (2011); Neb. ReV. STAT. § 53-216 (2011); N.J. STAT. ANN. $§ 56: 10-7$ (West 2012); R.I. GEN. LAWS $\S 16-28.1-19$ (2011); WASH. REV. CODE $\S 19.100 .180$ (2004).

93. See, e.g., Dunafon v. Taco Bell Corp., No. 93-4490-CV-C-9, 1996 U.S. Dist. LEXIS 22026, at *17-18 (W.D. Mo. Mar. 13, 1996); Cherick Distribs., Inc. v. Polar Corp., 669 N.E.2d 218, 220 (Mass. App. Ct. 1996).

94. See Matt Ellis, Franchisor Retaliation: A Thing of the Past?, Blue MauMau (July $30, \quad 2010, \quad 11: 46 \quad$ AM), http://www.bluemaumau.org/ franchisor_retaliation_thing_past ("[M] any franchisees who organize new associations feel they are targeted by their franchisors-even if they can't prove it."); infra notes 95109 and accompanying text.

95. See Robert W. Emerson, Franchise Contract Clauses and the Franchisor's Duty of Care Toward lts Franchisees, 72 N.C. L. REV. 905, 392-34, 954-55 (1994) (arguing that the franchise relationship affords franchisors so much discretionary power that for many franchise contract clauses the franchisor should be held to a higher standard of care than simply the implied covenant of good faith and fair dealing); W. Michael Garner, The Implied Covenant of Good Faith in Franchising: A Model for Discretion, 20 OKLA. CITY U. L. REV. 305, 321 (1995) (arguing that franchise contracts frequently make certain actions expressly subject to the franchisor's discretion); James Goniea \& Jeffrey Haff, Termination, Nonrenewal, and Transfer, in FRANCHISE Law ComplianCE MANUAL 351, 366 (Jeffrey A. Brimer ed., 2d ed. 2011) (citing numerous cases and discussing how franchisor discretion may challenge and undermine the franchisee's reasonable contractual expectations).

96. See Elizabeth C. Spencer, Balance of Power, Certainty and Discretion in the Franchise Relationship: An Analysis of Contractual Terms, BOND UNIVERSITY EPUBLICATIONS 13 (June 21, 2008), http://epublications.bond.edu.au/cgi/viewcontent.cgi ?article $=1248 \&$ context $=$ law pubs. Indeed, antitrust laws may incentivize franchisors not to cooperate with franchisees or their associations in the forming of "network expansion restrictions" or in the setting of prices. See Frederic Cohen, Michael Garner \& Erik Wulff, Potential Liabilities of Franchisors and Franchisee Associations for Concerted Actions 7-8 (May 1997) (unpublished manuscript) (on file with authors).

97. See Spencer, supra note 96 , at 19; see, e.g., Hengel, Inc. v. Hot 'N Now, Inc., 825 F. Supp. 1311, 1323 (N.D. Ill. 1993) (describing franchise agreements that promise 
addition, franchise contracts will give the franchisor discretion to choose whether or not to renew the franchise at the end of the contract relationship. ${ }^{98}$

In choosing to renew, franchisors will have discretion over the terms of the renewed franchise contract. Typically, the franchisor can add higher fees to the renewed contract as well as new restrictions on the operation of the franchise unit. ${ }^{99}$ A franchisor may also have discretion to require a franchisee to purchase from a supplier whose products are more expensive than the market price. ${ }^{100}$ In some cases, a franchisor will have discretion over whether to approve the franchisee's request to transfer her franchise unit to a third party. ${ }^{101}$ Moreover, a franchisor may have authority to change certain aspects of the franchise contract, including the franchise operations manual, computer systems, and level of control over franchisee premises. ${ }^{102}$ Similarly, a franchisor is often able to dictate the amount of training that it provides to a franchisee. ${ }^{103}$ A franchisor may also have discretion over whether to approve the franchisee's request to establish or operate another business similar to the franchise business. ${ }^{104}$ Finally, franchisors may have discretion-which is respected by most states-to terminate the franchise contract "at will," i.e., without a material breach on the part of the franchisee. ${ }^{105}$

that the franchisor will make promotional and marketing information and advice available "as may periodically be developed and deemed by the Company to be helpful").

98. See Spencer, supra note 96 , at 16.

99. See id. at 18.

100. See id. at 23 .

101. See id. at 27; see, e.g., Popeyes, Inc. v. Tokita, Civ. A. Nos. 87-3011, 90-1179, 1993 U.S. Dist. LEXIS 13295, at *30 (E.D. La. Sept. 21, 1993).

102. See Bonfield v. AAMCO Transmissions, Inc., 708 F. Supp. 867, 885 (N.D. Ill.

1989); Garner, supra note 95, at 307; Spencer, supra note 96, at 35-36.

103. See Spencer, supra note 96 , at 35.

104. See H\&R Block E. Tax Servs., Inc. v. Vorpahl, 255 F. Supp. 2d 930, 933 (E.D. Wis. 2003) (upholding a franchise agreement provision barring a franchisee from opening a similar business during the term of the franchise agreement); Gen. Motors Corp. v. New A.C. Chevrolet, Inc., 91 F. Supp. 2d 733, 739 (D.N.J. 2000) (upholding a franchise agreement provision barring a franchisee dealership from opening up a competing dealership at the franchise location), aff'd, 263 F.3d 296 (3d Cir. 2001); see also Spencer, supra note 96 , at 35 .

105. See Jonathan Klick et al., The Effect of Contract Regulation: The Case of Franchising 8 (George Mason Law \& Econ. Research Paper Series, Working Paper No. 07-03, 2006), available at http://ssrn.com/abstract $=951464$ ("[M]ost franchise contracts contain at will termination clauses."). At any rate, if a clause more precisely justifying a termination were needed, such a clause could very likely be found in the written franchise agreement. See Robert W. Emerson, Franchise Contract Interpretation: A Two-Standard Approach, 2013 MiCH. ST. L. REV. (forthcoming) (examining 100 franchise contracts in 1993 and 100 franchise contracts in 2013 and showing that 100 percent of these contracts, for both years, had clauses expressly delineating reasons for franchise termination, such as the franchisee's insolvency, loss of lease, failure to do business, 
Once the franchisor makes a discretionary decision that financially harms the franchisee association leader, the leader may have difficulty proving that the franchisor's intent was retaliatory. Providing compelling evidence of the franchisor's mental state and subjective intentions is a very challenging task. ${ }^{106}$ The franchisor-usually a sophisticated business entity supported by legal consultants-is likely to be careful not to draw an explicit and manifest connection between the harmful discretionary decision and the acts taken by the franchisee association leader prior to the franchisor's decision. ${ }^{107}$ Cases of retaliation, therefore, are difficult to prove because a franchisor neither declares that retaliation was a motive for his actions nor leaves a welldeveloped trail demonstrating his motive. The franchisor actually has an incentive to produce information about those intentions that will demonstrate that the action was not taken in retaliation. ${ }^{108}$ In fact, it is a relatively simple task for franchisors to concoct plausible business reasons for discretionary decisions they may have made against the franchisee association leader. ${ }^{109}$

Given the inherent difficulty of proving retaliation in many areas of law, policymakers have crafted evidence rules that are aimed to facilitate the proof of reprisal. For example, under certain labor laws, an employer's actions or response to an employee engaging in a protected act may raise an initial inference of retaliation. ${ }^{110}$ Similarly, under the

conduct of an illegal enterprise, finding of criminal guilt, business abandonment, or denial of franchisor inspections).

106. For a similar argument in the field of employment law and landlord-tenant law, see Sarah Carrington Walker Baker, $A$ Choice of Rules in Title VII Retaliation Claims for Negative Employer References, 55 DUKE L.J. 153, 169 (2005); Marcia L. McCormick, The Truth Is Out There: Revamping Federal Antidiscrimination Enforcement for the Twenty-First Century, 30 BerKeLEY J. EMP. \& LAB. L. 193, 211-12 (2009); Emily A. Spieler, Perpetuating Risk? Workers ' Compensation and the Persistence of Occupational Injuries, 31 Hous. L. Rev. 119, 230 (1994); Lauren A. Lindsey, Comment, Protecting the Good-Faith Tenant: Enforcing Retaliatory Eviction Laws by Broadening the Residential Tenant's Options in Summary Eviction Courts, 63 OKLA. L. REV. 101, 115 (2010).

107. See Carl E. Zwisler \& Mitchell S. Shapiro, Representing and Dealing with Franchisee Associations 18 (Oct. 11-13, 1995) (unpublished manuscript) (on file with authors).

108. See Baker, supra note 106, at 168.

109. Cf. Parada v. Great Plains Int'l of Sioux City, Inc., 483 F. Supp. $2 d$ 777, 791 (N.D. Iowa 2007) ("Because adverse employment actions almost always involve a high degree of discretion, and most plaintiffs in employment discrimination cases are at will, it is a simple task for employers to concoct plausible reasons for virtually any adverse employment action ranging from failure to hire to discharge.").

110. See, e.g., Hossaini v. W. Mo. Med. Ctr., 97 F.3d 1085, 1089 (8th Cir. 1996) (discussing actions by an employer that can lead to an inference of retaliation in the employment context); see also PAUl M. IgASAKI, 6 Digest of Equal EMPloyment OPPORTUNITY LAW 1, 8-18 (1998), available at $\mathrm{http}: / /$ www.eeoc.gov/policy/docs/retal.pdf (describing that a close proximity in time 
landlord-tenant laws of several states, if a landlord's alleged act of retaliation has occurred shortly after a tenant has organized a tenant's organization, such act shall be presumed to be retaliatory. ${ }^{111}$ In franchise law, however, there are no such evidence rules that aim to facilitate the franchisee's proof of retaliation or pretext. Conversely, some courts have ruled that the fact that a franchisor's alleged act of retaliation occurred shortly after a protected activity conducted by the franchisee does not necessarily give rise to a presumption of retaliatory intent. ${ }^{1 / 2}$

\section{B. Low Expected Benefits for Franchisee Association Leader}

The weak incentive to form an independent franchisee association is further diminished by the low probability that the leading franchisee will succeed in forming a sustainable association that has enough members to influence the franchisor. The establishment of an independent franchisee association faces two deterring obstacles: first, franchisors often establish, fund, and control a franchisees' committee, known as a franchisor advisory council, which serves franchisors as a tool to reduce significantly the probability that an independent franchisee association will survive; and second, an individual franchisee has little incentive to join and actively participate in an independent franchisee association once it is formed. These two obstacles are now considered in turn.

\section{Franchisor Advisory Council Barriers}

A franchisor advisory council ("FAC") is a committee of franchisees, established by the franchisor, ${ }^{13}$ that meets with franchisor executives on a regular basis. ${ }^{114}$ Normally, the central purpose of a FAC is to promote communication between franchisees and franchisors on

between the employee's protected action and the employer's alleged retaliatory response can raise an inference of retaliation).

111. See, e.g., DEL. CODE ANN. tit. $25 \S 5516(\mathrm{c})$ (2009); IOWA CODE $\S 562 A .36(2)$ (1979); R.I. GEN. LAWS § 34-18-46(b) (1986); see also ARIZ. REV. STAT. ANN. § 331381(B) (1973); Ky. Rev. Stat. ANN. § 383.705 (West Supp. 1984); ME. Rev. Stat. ANN. tit. 14, § 6001(3) (Supp. 1975).

112. See, e.g., Harara v. ConocoPhillips Co., 377 F. Supp. 2d 779, 791 (N.D. Cal. 2005).

113. See Gladys Glickman, Franchising § 3.03[6] (rev. ed. 2012); Keith J. Kanouse \& H. Stephen Brown, AAFD's "Fair Franchising Standards": The Case For, 16 FRANCHISE L.J. 59, 60 (1996); Zwisler \& Shapiro, supra note 107, at 2.

114. See Franchise Tutorial 10: Intro to Franchise Advisory Councils, CAN. FRANCHISE Ass'N (Jan. 2011) [hereinafter Franchise Tutorial 10], http://www.cfa.ca/ Publications_Research/Tutorials/tutoriall 0.aspx. Franchisor advisory councils are known by various names, including advisory councils, franchisee advisory boards, or councils. See Eric B. Wulff, Advisory Councils: Effective Two-Way Communications for Franchise Systems, INT'L FRANCHISE Ass'N 3 (2005), http://www.franchise.org/files/ Advisory\%20Councils.pdf. 
franchise-related matters, such as advertising, field support, operations, and changing market trends. ${ }^{115}$ FACs are, by their very own definition, advisory. ${ }^{116}$ As a purely advisory group, FAC recommendations are not binding on the franchisor. ${ }^{117}$

Franchisors tend to absorb all of the organizational expenses of the FAC, including paying franchisee FAC members the travel and living expenses incurred to participate in FAC meetings. ${ }^{118}$ In addition, the franchisor typically exerts a significant amount of control over the activities of the FAC. ${ }^{119}$ For example, the franchisor usually prepares the FAC's governing documents, sets up the method for the selection of FAC members, and announces the conditions for membership. ${ }^{120}$ Similarly, the franchisor controls the FAC meeting agendas and schedules. ${ }^{121}$ FACs have been quite common within franchise systems since the early days of franchising. ${ }^{122}$ Today, most franchisors have established FACs. ${ }^{123}$

Interestingly, FACs are different from independent franchisee associations. While the typical goal of franchisee associations is to promote franchisees' bargaining power vis-à-vis the franchisor, ${ }^{124} \mathrm{FACs}$

115. See Franchise Tutorial 10, supra note 114; Janet Sparks, Franchise Advisory Council, BLUE MAUMAU, http://www.bluemaumau.org/franchise_advisory_council; Wulff, supra note 114, at 3. Other stated purposes of FACs may include: enabling the franchisors to obtain input and advice from franchisees; improving franchisee understanding of the franchise system; improving the working relationship between franchisor and franchisees; and providing legitimacy for franchisor decisions by getting franchisee input in the decision-making purpose. See Gurnick \& Wharton, supra note 73, at 4 ; Zwisler \& Shapiro, supra note 107 , at 2.

116. See Rupert M. Barkoff \& Diane Green-Kelly, Selected Antitrust and Other Issues Involving Franchisee Associations and Purchasing Cooperatives 3 (Oct. 11-13, 2006) (unpublished manuscript) (on file with authors); Rupert M. Barkoff, Franchise Associations: Nothing to Fear but Fear Itself, Usually, INT'L FRANCHISE Ass'N, http://www.franchise.org/franchise-news-detail.aspx?id=31104 (last visited Aug. 19, 2013).

117. See Rochelle B. Spandorf \& Rupert M. Barkoff, Close Encounters: Franchisee Associations and Councils 14 (Oct. 22-24, 2003) (unpublished manuscript) (on file with authors).

118. See Kanouse \& Brown, supra note 113, at 60; Einbinder \& Karp, supra note 13, at 5; Schumacher et al., supra note 49 , at 3; Spandorf \& Barkoff, supra note 117, at 16; Zwisler \& Shapiro, supra note 107 , at 8.

119. See Kolman \& CHERnow, supra note 41, at 22; Barkoff \& Green-Kelly, supra note 116, at 3; Zwisler \& Shapiro, supra note 107, at 2; Barkoff, supra note 116 ("FACs are usually formed ... in large measure, under the control of the franchisor.").

120. See Barkoff \& Green-Kelly, supra note 116 , at 3.

121. See id.; Barkoff, supra note 116.

122. See Barkoff \& Green-Kelly, supra note 116, at 1 .

123. See Rupert M. Barkoff, Collective Bargaining in Franchise Environments, N.Y. L.J., Nov. 17, 2010, at $3, \quad$ available at http://www.kilpatricktownsend.com/ /media/Files/articles/201 1/RBarkoff\%20Collective $\% 20$ Bargaining.ashx; Wulff, supra note 114 , at 4.

124. See Coldwell, supra note 39 , at 2. 
lack any real bargaining power, and they are incapable of serving as useful collective bargaining agents for franchisees for several reasons. ${ }^{125}$ First, the bylaws of FACs usually emphasize their communicative role and do not provide franchisees with the power to negotiate the terms of the franchise contract that governs the relationship between franchisee and franchisor. ${ }^{126}$ Second, FACs are most often fully funded by franchisors, which compromises FACs' ability to represent franchisees effectively. ${ }^{127}$ Third, FAC members normally do not have an incentive to oppose aggressive franchisor policies, or to represent genuinely the interests of the franchisee community. ${ }^{128}$ The seductive promises of future benefits from franchisors, including renewal of franchise contracts or approval to open new units, are likely to induce FAC members to place their loyalties with franchisors, rather than with fellow franchisees. ${ }^{129}$ FACs, therefore, frequently are viewed not as representative of franchisees' interests but, instead as shills of franchisors composed of franchisees courting favor with franchisors. ${ }^{130} \mathrm{FAC}$ leaders are often thought of as working more for the benefit of franchisors than the franchisees. ${ }^{131}$

125. See GLICKMAN, supra note 113 (stating that "[a FAC] typically is not formed to represent the interests of the franchisees," but rather to "provide a channel of communication between the franchisees and the franchisor"); Emerson, supra note 76, at 1537 (noting that a FAC "definitely is not a collective bargaining agent"); Lawrence \& Kaufmann, Identity in Franchise Systems, supra note 13, at 287-88 ("Although ostensibly designed to represent franchisee interests, FACs are often unidirectional communication devices through which the franchisor speaks to their franchisees, and [they] are typically viewed as lacking sufficient authority or power to demand change."); Spandorf \& Barkoff, supra note 117, at 26.

126. See Emerson, supra note 76, at 1537.

127. See Einbinder \& Karp, supra note 13, at 5.

128. See Spandorf \& Barkoff, supra note 117, at 16 ("FAC members tend to be less adversarial and more consultative than the IFA leadership.").

129. Cf. Mark Barenberg, Democracy and Domination in the Law of Workplace Cooperation: From Bureaucratic to Flexible Production, 94 CoLUM. L. REV. 753, 877 (1994) ("The company union served in part 'as a sort of selection agency through which those representatives who serve the company with unswerving loyalty are promoted to higher positions.' Much evidence confirms that representatives knew they stood to gain foremen or supervisory positions as a reward for being good 'company men.' ... The seductions of promotional opportunities, status, perquisites, and constant 'education' in management's viewpoint generally succeeded in aggregating a loyalist cadre. ...").

130. See Ted P. Pearce \& Rupert M. Barkoff, Collective Bargaining and the Franchise Agreement: Finding the Middle Ground 6 (Oct. 10-12, 2001) (unpublished manuscript) (on file with authors).

131. See Lawrence \& Kaufmann, Identity in Franchise Systems, supra note 13, at 291. Sometimes the franchisor selects the franchisees who will sit on the FAC. In such cases, the franchisor will select loyal franchisees rather than franchisees that are perceived by her as "trouble makers." GLICKMAN, supra note 113, at § 3.03[6]; Spandorf \& Barkoff, supra note 117, at 11 . 
FACs often reduce the potential effectiveness of independent franchisee associations. At the outset, franchisors often use the FAC as a device to justify refusing to negotiate with the independent franchisee associations. $^{132}$ Specifically, franchisors often refuse to negotiate with independent franchisee association members by claiming that the franchisees' concerns are addressed through the FAC. ${ }^{133}$ For example, Taco Bell refused to negotiate with an independent franchisee association within its chain because Taco Bell had formed a FAC where franchisees could present their views on company policy. ${ }^{134}$ Likewise, when a group of Mail Box Etc. franchisees formed an independent franchisee association, the franchisor declined to recognize the association and responded by directing the franchisee association to communicate with the franchisor through the FAC. ${ }^{135}$

The franchisor's refusal to negotiate with franchisees through the independent franchisee association reduces the probability that the association will endure. More specifically, by refusing to negotiate with the association, the franchisor undermines the central goal of the independent franchisee association: to maintain a strong position in negotiations with the franchisor regarding franchise contract terms. Undermining the association's goal is likely to reduce the incentive of franchisees to join and support the association. ${ }^{136}$ Indeed, the weakness

132. See Kanouse \& Brown, supra note 113 , at 60 . This is simply an excuse in that ordinarily, regardless of whether a franchisor has a FAC, it may choose to negotiate, or not, with an independent franchisee association.

133. See Wendy Webb, MBE Redesign Sparks Association Formation, WIKIDFraNCHISE (Aug. 1, 2000), http://www.wikidfranchise.org/20000801-mberedesign.

134. LUXENBERG, supra note 47 , at 270.

135. Ballon, supra note 17; Schumacher et al., supra note 49, at 6-8. Apparently, the Jackson Hewitt franchisor also said it prefers communicating with franchisees through the existing FAC. Ballon, supra note 17; see also Lawrence \& Kaufmann, Franchisee Associations, supra note 41 , at 150 (noting the frequent statements from a Quiznos franchisor arguing that a FAC already exists to address franchisee concerns); Don Sniegowski, Fight Escalates Between Super 8 Franchise Owners and Their Franchisor, BLOOMBERG BUSINESSWEEK (Jan. 19, 2010), http://www.businessweek.com/smallbiz/ running_small business/archives/2010/01/corporate franc.html (reporting how a hotel chain established and in effect controlled a franchise advisory council while endeavoring to ignore and undermine the independent franchise association for the franchisees of the chain).

136. Cf. Franks Bros. v. NLRB, 321 U.S. 702, 704 (1944) ("[U]nlawful refusal of an employer to bargain collectively with its employees' chosen representatives disrupts the employees' morale, deters their organizational activities, and discourages their membership in unions."); Archibald Cox, The Duty to Bargain in Good Faith, 71 HaRV. L. REV. 1401, 1408 (1958) ("The denial of recognition is an effective means of breaking up a struggling young union too weak for a successful strike. After the enthusiasm of organization and the high hopes of successful negotiations, it is a devastating psychological blow to have the employer shut the office door in the union's face."); Ethan Lock, The Scope of the Labor Exemption in Professional Sports, 1989 DUKE L.J. 
of associations may reduce the chances for franchise legislation. In a spiraling downward effect, the associations' weakness may lower the incentive for franchisees to join associations that appear to be ineffective both in their dealings with the franchisor and in their efforts to achieve systemic reform via new statutes or regulations. ${ }^{137}$

Once again, it must be noted that this franchise law framework, in which franchisors that establish FACs refuse to negotiate with independent franchisee associations, contradicts the public policies that underlie labor law. ${ }^{138}$ For example, federal law specifically prohibits employers from refusing to bargain collectively with the representatives of their employees because of the potential harm that a refusal to negotiate with a labor union may cause to the union's existence. ${ }^{139}$ Under franchise law, however, this same behavior by franchisors is not prohibited. ${ }^{140}$

In addition, FACs reduce the potential effectiveness of independent franchisee associations in another way. Sometimes, franchise chains with FACs also appear to have, at least for a certain period of time, independent franchisee associations. ${ }^{141}$ In such cases, members of the FAC also may be members of the independent association. ${ }^{142}$ Therefore, considerations of divided loyalties and confidentiality prevent the FAC members from operating effectively within the independent

339,413 n.389 ("An employer's refusal to bargain or other misconduct, if allowed to continue, may gradually erode employee support for the union.").

137. That is certainly the pattern concerning union strength and membership. See Ellen J. Dannin, We Can't Overcome? A Case Study of Freedom of Contract and Labor Law Reform, 16 BERKELEY J. EMP. \& LAB. L. 1, $150 \mathrm{n} .838$ (1995) (suggesting that "weak unions are unable to achieve favorable legislation"); Ann C. Hodges, Lessons from the Laboratory: The Polar Opposites on the Public Sector Labor Law Spectrum, 18 CORNELL J.L. \& PUB. POL'Y 735, 756-57 (2009) (suggesting that less union strength diminishes the chances of new legislation, and that without new legislation, union membership will remain low); see also Terry Thomason, From Uniformity to Divergence: Industrial Relations in Canada and the United States, 48 IndUS. \& LAB. REL. REV. 371, 372 (1995) (reviewing PradeEP KuMAR, From UNIFORMITY to DIVERGENCE: INDUSTRIAL RELATIONS IN CANADA AND THE UNITED STATES (1993)) (noting the author's implication "that the chain of causation is from union strength to legislation rather than vice-versa").

138. Admittedly, franchisees and employees are distinguishable from one another and should, therefore, be treated differently in certain contexts. See, e.g., Robert W. Emerson, Franchisees in a Fringe Banking World: Striking the Balance Between Entrepreneurial Autonomy and Consumer Protection, 46 AKRON L. REV. 1 (2013). However, this does not appear to be the case for rights with respect to associations.

139. National Labor Relations Act, 29 U.S.C. $\$ 158(a)(5)$ (2006).

140. Likewise, because employer-controlled unions ("company unions") may hurt employees' incentives to form independent unions, federal law prohibits employers from establishing company unions. Id. $\S 158(\mathrm{a})(2)$. In franchise law, though, franchisors can form FACs. Emerson, supra note 76, at 1538-39.

141. See Zwisler \& Shapiro, supra note 107 , at 9.

142. Schumacher et al., supra note 49 , at 25 . 
association. ${ }^{143}$ In addition, the presence of fellow franchisees that are part of the competing FAC may make some members of the independent association uncomfortable. ${ }^{144}$ Indeed, in franchise systems in which FACs and independent franchise associations co-exist, franchisee factions will often spawn. ${ }^{145}$

Given the potential of FACs to reduce the effectiveness of independent franchisee associations, it is not surprising that the subjective franchisor motive underlying the establishment of the FAC often is to hinder the existence or operation of independent franchisee associations. ${ }^{146}$ Likewise, it is also not surprising that when a FAC is formed after a franchisee association has been established, franchisees often subjectively view that franchisor-sponsored FAC as a threat to their association. ${ }^{147}$

\section{Franchisees' Weak Incentive to Support an Association}

An individual franchisee typically has little, if any, incentive to join and to participate actively in an independent franchisee association. Three major reasons explain this lack of incentive. First, each individual franchisee has a basic incentive to free-ride on the efforts of other franchisees that will support the independent association ${ }^{148}$ because all franchisees commonly share the same benefits from the association's collective bargaining power whether they actively participate in the association or not. ${ }^{149}$ Second, most franchisees are unlikely to join and participate actively in the association because they fear that the franchisor will take harmful retaliatory actions against them if they do so.

143. See William A. Darrin et al., The Role of Trade Associations and Franchisee Associations in Franchising 20 (Oct. 28-30, 1998) (unpublished manuscript) (on file with authors); Schumacher et al., supra note 49 , at 25 .

144. See Schumacher et al., supra note 49 , at 25.

145. See Spandorf \& Barkoff, supra note 117 , at 1 .

146. See Harold Brown, FranChisInG: REALITIES AND ReMEdiES § 4.02[1], at 4-38 (rev. ed. 2003); Emerson, supra note 76, at 1504; Carmen D. Caruso, Ten Legal Issues Facing Independent Franchise Associations 3 (Apr. 28-May 1, 2004) (unpublished manuscript), available

at http://www.stahlcowen.com/956B90/assets/files/lawarticles/Ten Legal Issues Facing New and Established Independent Franchisee Associations.rtf; Gurnick \& Wharton, supra note 73, at 5, 11; Schumacher et al., supra note 49, at 3, 6 .

147. See Spandorf \& Barkoff, supra note 117, at 11.

148. See Richard Solomon, Why Are There So Few Effective Franchisee Associations?, BLUE MAUMAU (July 12, 2009, 7:47 AM), http://www.bluemaumau.org/ why_are_there_so_few_effective_franchisee_associations; Les Stewart, $A$ Man in Debt is So $\bar{F}$ ar $\bar{a}$ Slave, FranchISE Fool (June 16, 2010), https://lesstewart.wordpress.com/tag/free-rider-problem/.

149. See Kenneth G. Dau-Schmidt, A Bargaining Analysis of American Labor Law and the Search for Bargaining Equity and Industrial Peace, 91 MiCH. L. REV. 419, 457 (1992). 
Indeed, one of the questions most frequently asked by franchisees at an association organizational meeting is: "What can my franchisor do to me if I join?"150 This fear is justifiable given that federal and most state laws do not adequately prohibit franchisors from taking retaliatory actions against franchisees that join or participate in the activity of an association. ${ }^{151}$ This fear is also understandable given that franchisees will normally find it difficult, under current law, to prove the subjective intent of retaliation on the part of the franchisor. ${ }^{152}$ Finally, some franchisees are unlikely to join the association because the franchisor will offer them economic benefits should they refrain from supporting the association. Indeed, some large franchisees have been known to

150. See Lawrence \& Kaufmann, Franchisee Associations, supra note 41, at 150 ("There is a perception among many Quiznos franchisees that dissent will be punished."); Einbinder \& Karp, supra note 13, at 19; Eric H. Karp et al., Rally 'Round the Flag: How, When and Why to Form an Independent Franchisee Association 2 (May 6-7, 1999) (unpublished manuscript) (on file with authors); Zwisler \& Shapiro, supra note 107, at 4 (noting that in their recruiting efforts, association founders need to overcome their colleagues' fear that they will become victims of overt or subtle retribution if they join).

151. See, e.g., Complaint, Glickman v. Krispy Kreme Doughnut Corp., No. BC340658 (Cal. Super. Ct. Sept. 30, 2005), 2005 WL 3032553 (reciting allegations of retaliation by largest franchisee of popular donut chain where franchisor changed its supply policies to require franchisee to buy all daily supplies from franchisor and then began "systematically inflating the prices" of such supplies to force franchisee out of business because franchisee refused to sell to franchisor-specific stores in the region and subsequently formed a franchisee association); see also Harara v. ConocoPhillips Co., 377 F. Supp. 2d 779, 791 (N.D. Cal. 2005) (discussing that even participating in a lawsuit against a franchisor does not necessarily create a presumption of retaliation without more evidence); George Lussier Enters. v. Subaru of New England, Inc., 122 F. Supp. 2d 231, 239 (D.N.H. 2000) (showing that the franchisor was "angry" at the plaintiff and that the franchisor had asked other franchisees not to participate in the plaintiff's litigation did not support a finding of the franchisor's "retaliatory motivation"); Magerian v. Exxon Corp., No. C-95-20293 RMW, 1996 WL 119481 (N.D. Cal. Mar. 11, 1996) (discussing that even participating in a lawsuit against a franchisor does not necessarily create a presumption of retaliation without more evidence); Munno v. Amoco Oil Co., 488 F. Supp. 1114, 1119 (D. Conn. 1980) (discussing how a franchisor's actions, if following the franchisor's own normal policy, will indicate good faith, as opposed to retaliation, on the part of the franchisor). But see Gilderhus v. Amoco Oil Co., 470 F. Supp. 1302, 1305 (D. Minn. 1979) (describing Congress' intent to prevent retaliation by franchisors in the oil franchise context and how the plaintiff had raised "serious questions as to whether the termination in this case was both discriminatory and retaliatory" where the plaintiff's franchise agreement was terminated while other franchisees who had engaged in the same conduct had not had their agreements terminated by the franchisor).

152. See, e.g., George Lussier Enters., 122 F. Supp. 2d at 240 (showing that the franchisor was "angry" at the plaintiff and that the franchisor had asked other franchisees not to participate in the plaintiff's litigation did not support a finding of the franchisor's "retaliatory motivation"); see also Pearman v. Texaco, Inc., 480 F. Supp. 767, 772 (W.D. Mo. 1979) (holding that a franchisor is entitled to make business judgments about the franchise relationship that may negatively impact the franchisee or the franchisee's business if such judgments are made "in good faith in the normal course of business"). 
make "sweetheart deals" with their franchisor in return for agreeing not to support the association. ${ }^{153}$

Anecdotal evidence confirms that most franchisees are unlikely to join and actively participate in an association once it is formed. For example, one in-house counsel stated that the franchisee association in his chain represents only one percent of all system members. ${ }^{154}$ Likewise, two attorneys serving as counsel to independent franchisee associations stated that many associations represent less than half of the system's franchisees. ${ }^{155}$ Similarly, the franchisee association at Curves International succeeded in collecting member fees from only 465 out of 5,830 total franchisees. ${ }^{156}$ The association ultimately failed, among other reasons, due to the unwillingness of franchisees to fund the association. $^{157}$ In another example, two other attorneys serving as counsel to independent franchisee associations stated that they have witnessed "the rise and quick fall of several franchisee associations who felt they could organize and represent the interest of their members and retain competent legal counsel for a per member fee of $\$ 50$ per year."

\section{Industry Data Support}

Franchise industry data, which have been accumulated over recent years and which so far have been overlooked in the debate over franchisee protection laws, suggest that in most cases, independent franchisee associations are unlikely to be established in the first place. The data reveal that out of approximately 3,000 franchise chains in the

153. See Gurnick \& Wharton, supra note 73 , at 11-12 (discussing circumstances in which franchisors persuade key franchisees to remain uninvolved or not to participate in an association); Karp et al., supra note 150, at 11.

154. Spandorf \& Barkoff, supra note 117 , at 6.

155. Pearce \& Barkoff, supra note 130 , at 6 . One example of this is Burger King's Minority Franchise Association. According to the Minority Franchise Association, Burger King has 7,830 franchisee-owned Burger King stores in the United States. Of that number, only 1,173 stores are minority-owned. Although the Minority Franchise Association is a national organization that has been in operation for 26 years, it only represents 75 of the 1,173 minority-owned franchises. See Burger King Minority Franchisees Respond to Boycott, QSR MAG. (Sept. 14, 2000), http:/www.qsrmagazine.com/news/burger-king-minority-franchisees-respond-boycott.

156. CFA Bids Farewell to the Curves Owners Community, CuRvES FRANCHISE

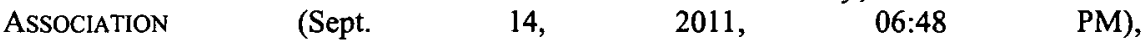
http://web.archive.org/web/20120815105851/www.curvesfa.org/content/cfa-bidsfarewell-curves-owners-community (accessible by searching for curvesfa.org in the Internet Archive index).

157. Curves: Why Did the Curves Franchisee Association Fail? (Part 1), UnHAPPY FRANCHISEE (Feb. 2, 2012), http://www.unhappyfranchisee.com/why-did-the-curvesfranchisee-association-fail-1/.

158. Zwisler \& Shapiro, supra note 107 , at 11. 
United States, ${ }^{159}$ only a few percent have independent franchisee associations.

An important body that presents such industry data is the American Association of Franchisees and Dealers ("AAFD"). The AAFD has dedicated over 20 years to supporting independent franchise associations. ${ }^{160}$ The AAFD particularly assists franchisees in establishing and operating independent franchisee associations. In fact, for a fee, the AAFD allows independent franchisee associations to launch an association affiliated with the AAFD's trademark. ${ }^{161}$ This affiliation is aimed, among other things, at allowing the affiliated associations to "achieve negotiating leverage with their franchisors, their suppliers and ultimately their customers, by developing vital marketing networks." 162 The goal of the affiliation is also to provide independent franchisee associations "the opportunity to network and share experiences with other franchisee associations and leaders and to develop solutions to common problems." ${ }^{163}$ According to AAFD President Robert Purvin, the AAFD has successfully identified about 120 U.S. franchise chains that have independent franchisee associations. ${ }^{164}$ This is only four percent of the estimated 3,000 franchise systems in the United States. ${ }^{165}$

Another important source of industry data, which supports this Article's theoretical argument that franchisee associations are, in most cases, unlikely to be established, is the International Association of Franchisees and Dealers ("IAFD"). The IAFD's central goal is to empower franchisees; ${ }^{166}$ it is oriented toward supporting independent

159. Mary Connell, Small Business Franchise Relations, ARTICLERICH, http://www.articlerich.com/Article/Small-Business-Franchise-Relations/932456 (last visited Aug. 19, 2013); Kevin Ghezzi, Service Franchises, Sell or Sink, INT'L Ass'N OF FRANCHISEES \& DEALERS (Aug. 24, 2012, 12:18 AM), http://www.franchiseinfo.ca/franchisee_association_news/2012/08/service-franchises-sell-or-

sink.html\#.UNqsfuRlmqI; Eddy Goldberg, Preparing for First Contact With a Franchisor,

FRANCHISING.COM, http://www.franchising.com/howtofranchiseguide/preparing_for_first_contact_with_a_fr anchisor.html (last visited Aug. 19, 2013).

160. Robert Purvin, Start a Franchisee Association as a Chapter of the AAFD, AM. Ass'N OF FrANCHISEES \& DEALERS (May 24, 2012), http://www.aafd.org/blog/start-afranchisee-association-as-a-chapter-of-the-aafd.

161. AAFD's Four Goals of Service, AM. Ass'N OF Franchisees \& Dealers, http://www.aafd.org/aafds-four-goals-of-service (last visited Aug. 19, 2013).

162. Id.

163. Purvin, supra note 160.

164. Don Sniegowski, Bob Purvin: "Franchisee Associations Are Growing But We Should Be Seeing More", Blue MauMau (July 15, 2008, 4:43 AM), $\mathrm{http} / / / \mathrm{www} . b l u e m a u m a u . o r g / 5841 /$ bob_purvin_franchisee_associations_are_growing_but _we_should_be_seeing_more.

165. Id.

166. Who We Are, INT'L Ass'N OF FRANCHISEES \& DEALERS, http://www.franchiseinfo.ca/about/about.html (last visited Sept. 6, 2013). 
franchisee associations. ${ }^{167}$ The LAFD's strategic committee includes legal counsel to numerous franchisee associations. ${ }^{168}$ Additionally, the IAFD provides educational data to independent franchisee associations. ${ }^{169}$ The IAFD also has an independent franchisee directory, ${ }^{170}$ which reveals that the IAFD succeeded to identify only 58 franchise chains that have independent franchisee associations. ${ }^{171}$

\section{CONCLUSION}

Franchisee protection laws have two central goals: first, to remedy the disparity of bargaining power between strong franchisors and weak franchisees; and second, to protect franchisees against perceived opportunism on the part of the franchisor. However, franchisor advocates uniformly conclude that these laws are undesirable. Their central claim is that independent franchisee associations reduce the inequality of bargaining power between franchisor and franchisees and, therefore, serve as a sufficient protection against franchisor opportunism. To date, most states have refused to adopt general franchisee protection laws, keeping in line with the franchisor advocates' view. Similarly, at the federal level, such laws have been rejected entirely.

This Article presents a challenge to the validity of franchisor advocates' analysis. In most cases independent franchisee associations are unlikely to be established by franchisees in the first place because a franchisee's expected costs for leading the establishment of an association exceed her expected benefits. Therefore, policymaker reliance on independent franchisee associations as a control against franchisor opportunism should be reassessed. Consequently, the door should be reopened to considering the adoption of franchisee protection laws.

167. See id.

168. Id.

169. The IAFD website has a section which includes resources for independent franchisee associations. See, e.g., Katrina Mitchell, Why Celebrity Speakers Fail at Franchise Conventions, INT'L Ass'N OF FranchiseEs \& DEALERS (Nov. 18, 2012, 8:31 PM), http://www.franchise-info.ca/resources/2012/11/why-celebrity-speakers-failat.html \#.UcXb5j7wJgw.

170. Directory of Independent Franchisee Associations, INT'L ASS'N OF FRANCHISEES \& DEALERS http://www.franchise-info.ca/about/directory-of-independent-franchiseeassociations.html (last visited Aug. 19, 2013).

171. Id. Many small franchised networks likely also have associations, which must account for larger estimates of the total number of associations. As of 2010, for example, it was estimated that there were at least 250 franchisee associations in the United States. Ten Most Powerful Franchise Associations, Blue MAuMau (July 23, 2010, 12:10 PM), $\mathrm{http}: / / \mathrm{www} . b l u e m a u m a u . o r g / 9125 / \mathrm{ten} \_m o s t$ powerful_franchise_associations. 